DOI: 10.17707/AgricultForest.62.3.18

\author{
Milan GAZDIĆ, Srđan PEJOVIĆ, Jelica GAZDIĆ, \\ Marko PEROVIĆ, Danka CAKOVIĆ ${ }^{1}$
}

\title{
FLORISTIC COMPOSITION AND ECOLOGYCAL ANALYSIS OF THE MIXED FORESTS (BEECH, FIR, SPRUCE) IN THE MANAGEMENT UNIT „BJELASICA“(BJELASICA Mt, MONTENEGRO)
}

\begin{abstract}
SUMMARY
Paper dealing with characteristics of the fir and beech association (AbietiFagetum moesiacae B. Jov. 1976.) and beech, fir and spruce association (PiceoFago-Abietetum Čol. 1965) on the territory of the management unit „Bjelasica“ (Mt Bjelasica, Montenegro). A total of 45 phytocoenological relevés were analysed, 34 for association Abieti-Fagetum moesiacae B. Jov. 1976. and 11 for association Piceo-Abieti-Fagetum Čol. 1965. In the beech and fir association significantly more plant species (60) were found compared to the association of beech, fir and spruce (30). Spectrums of life forms and areal types were made for these associations. In the fir and beech association, in spectrum of life forms phanerophytes are dominant (37.28\%), followed with hemicryptophytes (35.59\%) and geophytes (23.73\%). In the second association hemicryptophytes are dominant with $40 \%$, while phanerophytes constitute $36.67 \%$, and geophytes $20 \%$. Within the spectrum of Abieti-Fagetum moesiacae areal types the most common is Euro-Asian areal type (33.33\%), followed by Holarctic (18.33\%) and central-European (16.66\%). Within the spectrum of Piceo-Fago-Abietetum Čol.1965 areal types the most frequent are central-European and Holarctic with $21.87 \%$ both, but large percent is constituted of Euro-Asian areal type (18.75\%).

Keywords: forest plant community, mixed forests, Bjelasica, Montenegro
\end{abstract}

\section{INTRODUCTION}

According to the First national forests inventory of Montenegro (MARD, 2013) fir and beech associations constitute $6.1 \%$ of the surface area covered with the forest or $11.8 \%$ of the total wood volume. Forests of fir, spruce and beech constitute $4.7 \%$ of the surface area or $10.7 \%$ of the total wood volume. Annual volume increment of these forests is from 9.6\% (fir and beech forests) till 10.3\% (fir, spruce and beech forests). Aforementioned forests have great economic value, but they are also significant regarding their ecological aspect.

On the most part of former Yugoslavia forest association Abieti-Fagetum s. l. is well noticeable and it represents one of the first associations in Europe that

\footnotetext{
${ }^{1}$ Milan Gazdić, Srđan Pejović, Jelica Gazdić, Marko Perović, Faculty of forestry, University of Belgrade, SERBIA, Danka Caković (corresponding author: danka.petrovic@t-com.me), University of Montenegro, Faculty of Natural Sciences and Mathematics, Department of Biology, MONTENEGRO

Notes: The authors declare that they have no conflicts of interest. Authorship Form signed online.
} 
was distinguished and analysed in details (Horvat, 1938). These forests construct climate-regional altitudinal belt within the range of 700/800 to $1700 / 1800 \mathrm{~m}$ altitude. Fir and beech forests on Dinarides represent the most stabile forest type that retains all important natural characteristics in spite of the external influences (Stefanović and Beus, 1991).

Piceo-Fago-Abietetum Čol. 1965 is specific three-dominant association, with equal involvement of all three edificators in natural conditions, and with very different relations in the forests that are managed during the longer period of time. This association is limited at the altitudinal belt (1000-1550 m a.s.l.) where beech and fir achieve optimal growth in height and thickness, but it can descend below at wetter and sheltered places. Historically, it is older forest type compared with beech, beech-fir and spruce-fir forest types; it is closer to the ancestral deciduous-conifer type of forest that was been characteristic for the most part of the mountainous refugium belt from Plješevice to the Rodopi (Horvat, 1950; Jovanović, 1967; Mišić, 1982).

Investigations in mixed forests of fir and beech, and fir, spruce and beech were provided on several localities in Montenegro, only, mostly on Ljubišnja Mt, inside the Biogradska Gora National Park (Čurović and Medarević, 2011; Čurović et al., 2011; Čurović et al., 2012, Čurović et al., 2013) and in the vicinity of Rožaje town (Martinović and Markišić, 2002). This research has included soil and phytocoenological studies, as well as structural, developmental and production characteristics of mixed forests. Investigations of biological and horological spectrums were not been provided, in spite that they are significant indicators of ecological conditions at some locality. Beside the phytocoenological characteristics of mixed forests in management unit "Bjelasica", analyses of those spectrums were done in our paper, with goal to expand the knowledge about these associations. Particularly interesting are data about forest communities of beech, fir and spruce, because investigated area is near to the southern border of distribution of this community and under certain maritime impact (Čurović et al., 2013).

\section{MATERIAL AND METHODS}

The investigation of the forests community was carried out during the summers 2014. and 2015. In total, 45 phytocoenological relevés were taken, 34 in association Abieti-Fagetum moesiacae B. Jov. 1976 and 11 in association Piceo-Abieti-Fagetum Čol. 1965. Dimensions of all phytocoenological relevés are $5 \times 20 \mathrm{~m}(100 \mathrm{~m} 2)$. Methodology of phytocoenological studies followed BraunBlanquet (1964). Phytocoenological relevés are grouped in the table where floristic composition of floors for each association is presented, and the degree of presence is given for each plant species. Identification of collected material was done according to Domac (1994), Pignatti (1982) and Tutin et al. (1964-80, 1993), and the nomenclature is in accordance with Euro+Med (2006). Life form classification is performed according to Raunkier, elaborated and updated by Ellenberg and Mueller-Dombois (1967). The categorisation of taxa to floral 
element is determined by Meusel et al. (1965, 1978, and 1992) and Pignatti (1982), while grouping of floral elements in areal types is performed according to the plant-geographical classification of Stevanović (1992).

Meaning of used acronyms is given in alphabetical order: Central European (CEUR), Central European Mediterranean (CEMED), Central European mountainous (CEM), Central South European mountainous (CSEM), Euro-Asian (EAZ), Holarctic (HOL), Cosmopolitan (KOSM), MediterraneanSub-Mediterranean (MED-SUBMED), Mediterranean Pontic (MED PONT), South European mountainous monttainous (SEM). Presentation of horological and biological spectrum includes species cover, not only their presence in phytocoenological relevés. Sintaxonomic names follow Tomić and Rakonjac (2013).

\section{Study area}

Investigation was carried out on the Bjelasica Mt, on their northern slopes, in management unit „Bjelasica“. Surface area of this unit is 9205 ha, while the surface area of the forests and forestland is $\mathbf{5 2 4 8 . 4}$ ha, and the natural tall forests cover $82 \%$ of them.

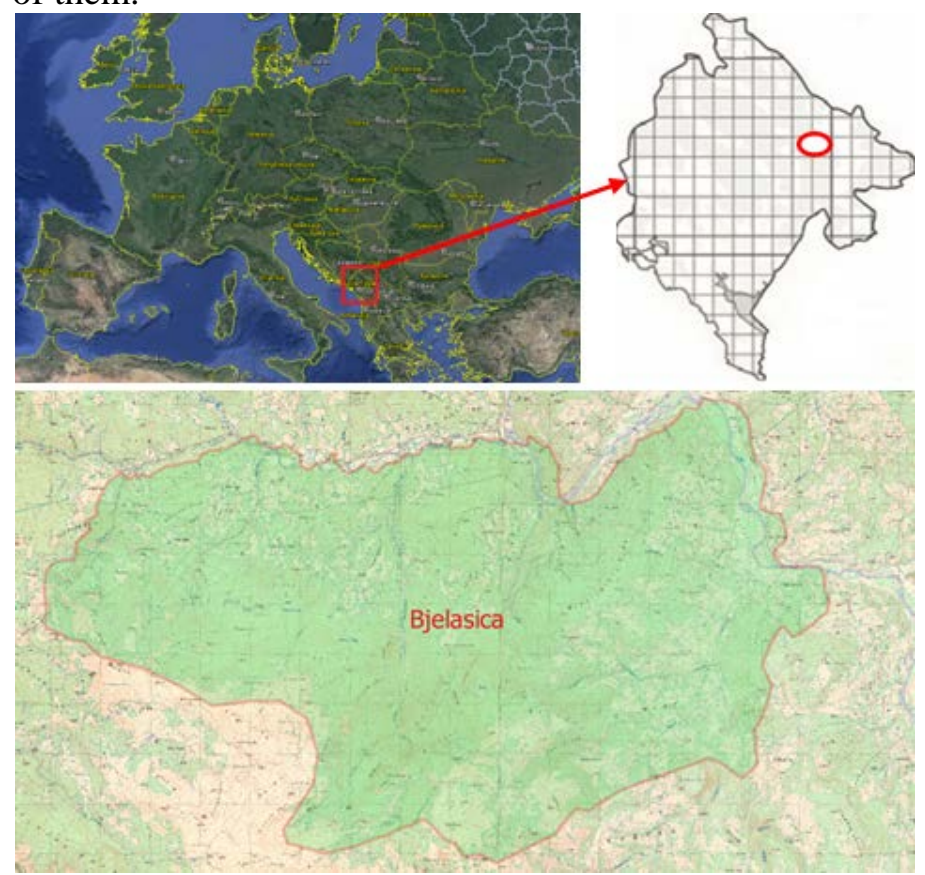

Figure 1. The position of investigated area.

The geological base and hydrology had significant influence during the process of relief forming. The geological groundwork is very heterogeneous, at higher altitudes the carbonate-silicate base prevails, while at the lower altitudes shale and sandstones predominate (Fuštić and Đuretić, 2000). The management unit is rich in water flows and springs with steep channels cut deep into the 
ground. The ridges, in north-south direction, lay between the water flows. Steep slopes are predominating in the management unit, and 53\% of the surface area covered with the forest are on the moderately steep terrains $\left(11-20^{\circ}\right)$ and $43 \%$ are on the steep terrains $\left(21-30^{\circ}\right)$. Terrain exposure to the north $(\mathrm{N}, \mathrm{NE}$ and $\mathrm{NW}$ ) constitutes $77 \%$ of the surface. The elevation of the lowest point in the management unit is $585 \mathrm{~m}$ a.s.l., and the highest elevation where the forest outreaches is $1850 \mathrm{~m}$ a.s.l.

The climate of the area is continental-mountainous perhumid, with long and cold winters and relatively short and coldish summers. The average annual temperature is $8.6^{\circ} \mathrm{C}$, according to the meteorological station in Bijelo Polje (560 $\mathrm{m}$ altitude), average annual precipitation is $922 \mathrm{l} / \mathrm{m} 2$ and the relative humidity is $78 \%$.

\section{RESULTS AND DISCUSSION}

The results content floral diversity and structure, spectrums of life forms and spectrums of areal types for fir and beech (Abieti-Fagetum moesiacae B. Jov. 1976.) and fir, spruce and beech associations (Piceo-Abieti-Fagetum Čol. 1965).

\section{Floristic somposition and structure}

In the community Abieti-Fagetum moesiacae B.Jov. 1976 ten species are recorded in the tree floor, from which only edificators have high level of permanence, while other taxa are sporadically noted. The shrub floor with 19 species is floristically richer, but only youth of edificators have high level of permanence, what was also noted on some other distributional areas of the association (Cvjetičanin and Novaković, 2010; Eremija et al., 2015). In the floor of herbaceous plants 58 species were recorded, and among them, except edificators, the remark level of presence possess Galium sylvaticum, Pteridium aquilinum, Lamium galeobdolon and Rubus ideus.

All floors of association Piceo-Abieti-Fagetum Čol. 1965 are floristically poorer compared with afore mentioned association. But, we must take in mind that the second association covers lesser surface area within the management unit, resulting in fewer number of made phytocoenological relevés during the investigation. The tree floor contents 6 species, while the shrub floor, beside edificators, contents only Corylus avelana, presented in small number of relevés. In the tree floor, besides edificators, the high permanence possesses a pioneer species Betula pendula. The flora of a ground-floor consists of 31 species, and the greatest permanence possesses Viola sylvestris and Luzula forstei, along with young specimens of beech and fir. High permanence is shown by youth of pioneer species Populus tremula, and this, along with high representing of Betula pendula in the tree floor, indicates a certain degree of forest degradation. Forests of spruce, fit and beech in the management unit "Bjelasica" are floristically poorer in all floors, compared to the forests with the same edificators on the mountain Lisina (Bosnia and Herzegovina) and Pešter plateau (Serbia) (Eremija et al., 2015). 
Floristic composition and ecologycal analysis of the mixed forests (beech, fir, spruce)... 211

Table 1. Floors coverage in associations

\begin{tabular}{|l|c|c|}
\hline & $\begin{array}{c}\text { Abieti-Fagetum moesiacae B.Jov. } \\
1976\end{array}$ & $\begin{array}{c}\text { Piceo-Abieti-Fagetum Čol. } \\
1965 .\end{array}$ \\
\hline Tree layer & 0,75 & 0,82 \\
\hline Shrub layer & 0,46 & 0,5 \\
\hline Herb layer & 0,38 & 0,33 \\
\hline
\end{tabular}

The floors coverage in associations is presented in table 1 . The coverage is somewhat greater in floors of trees and shrubs in the community Piceo-AbietiFagetum Col. 1965, while in the community of beech and fir the coverage is greater in the flora of the ground-floor.

Table 2. Phytocenological data

\begin{tabular}{|c|c|c|c|c|}
\hline & Life form & Areal types & $\begin{array}{c}\text { Abieti-Fagetum } \\
\text { moesiacae }\end{array}$ & $\begin{array}{l}\text { Piceo-Abieti- } \\
\text { Fagetum }\end{array}$ \\
\hline Number of relevés & & & 34 & 11 \\
\hline Species & & & I layer & \\
\hline Abies alba Mill. & P scap & SEM & $\mathrm{V}$ & $\mathrm{V}$ \\
\hline $\begin{array}{l}\text { Fagus moesiaca (K. Maly) } \\
\text { Czecz. }\end{array}$ & P scap & CEUR & V & V \\
\hline Picea abies (L.) Karst & P scap & EAZ & & $\mathrm{V}$ \\
\hline Betula pendula Roth. & P scap & EAZ & II & IV \\
\hline Ostrya carpinifolia Scop., & P scap & MED-SUBMED & $\mathrm{I}$ & I \\
\hline Populus tremula $\mathrm{L}$. & P scap & EAZ & I & \\
\hline Acer pseudoplatanus L. & P scap & CEMED & I & \\
\hline Pinus nigra Arnold & P scap & CSEM & I & \\
\hline $\begin{array}{l}\text { Quercus petraea (Matt.) } \\
\text { Lieblein }\end{array}$ & P scap & CEMED & I & \\
\hline Salix caprea L. & P caesp & EAZi & I & \\
\hline Pyrus pyraster Burgsd. & P scap & EAZ & $\mathrm{I}$ & \\
\hline \multirow[t]{2}{*}{ Fraxinus excelsior L. } & P scap & CEUR & & $\mathrm{I}$ \\
\hline & & & II 2 layer & \\
\hline Abies alba Mill. & P scap & CEM & $\mathrm{V}$ & III \\
\hline $\begin{array}{l}\text { Fagus moesiaca (K. Maly) } \\
\text { Czecz. }\end{array}$ & P scap & CEUR & V & V \\
\hline Picea abies (L.) Karst & P scap & EAZ & I & $\mathrm{V}$ \\
\hline Corylus avellana $\mathrm{L}$. & P caesp & EAZ & I & I \\
\hline Betula pendula Roth. & P scap & EAZ & I & \\
\hline Populus tremula $\mathrm{L}$. & P scap & EAZ & I & \\
\hline Acer pseudoplatanus L. & P scap & CEMED & I & \\
\hline Fraxinus excelsior L. & P scap & CEUR & I & \\
\hline
\end{tabular}




\begin{tabular}{|c|c|c|c|c|}
\hline Pinus nigra Arnold & P scap & CSEM & I & \\
\hline Ostrya carpinifolia Scop. & P scap & MED-SUBMED & I & \\
\hline $\begin{array}{l}\text { Quercus petraea (Matt.) } \\
\text { Lieblein }\end{array}$ & P scap & CEMED & I & \\
\hline Salix caprea L. & $\mathrm{P}$ caesp & EAZ & I & \\
\hline Pyrus pyraster Burgsd. & P scap & EAZ & I & \\
\hline Juniperus communis L. & P caesp & HOL & I & \\
\hline Crategus oxyacantha L. & P caesp & EAZ & I & \\
\hline Alnus incana (L.) Moench. & $\mathrm{P}$ caesp & HOL & I & \\
\hline Sambucus nigra L. & P caesp & EAZ & I & \\
\hline Rossa canina L. & NP caesp & EAZ & I & \\
\hline \multirow[t]{2}{*}{ Prunus avium L. } & P scap & EAZ & I & \\
\hline & & & III layer & \\
\hline $\begin{array}{l}\text { Fagus moesiaca (K. Maly) } \\
\text { Czecz. }\end{array}$ & P scap & CEUR & $\mathrm{V}$ & $\mathrm{V}$ \\
\hline Abies alba Mill. & P scap & CEM & IV & IV \\
\hline Galium sylvaticum L. & H scap & CEUR & IV & II \\
\hline $\begin{array}{l}\text { Pteridium aquilinum (L.) } \\
\text { Kuhn }\end{array}$ & G rhiz & KOSM & III & II \\
\hline $\begin{array}{l}\text { Lamium galeobdolon (L.) } \\
\text { Crantz }\end{array}$ & H scap & CEUR & III & III \\
\hline Rubus idaeus L. & NP rept & HOL & III & I \\
\hline Viola silvestris Lam. & H scap & CEMED & II & $\mathrm{V}$ \\
\hline Luzula forsteri (Sm.) DC & H caesp & HOL & II & $\mathrm{V}$ \\
\hline Rubus fruticosus L. & NP rept & MED-SUBMED & II & II \\
\hline Oxalis acetosella L. & G rhiz & HOL & II & I \\
\hline $\begin{array}{l}\text { Aremonia agrimonioides (L.) } \\
\text { DC }\end{array}$ & $\mathrm{H}$ ros & CSEM & II & I \\
\hline Galium rotundifolium L. & H scap & CEUR & II & I \\
\hline Picea abies (L.) Karst & P scap & EAZ & I & III \\
\hline Betula pendula Roth. & P scap & EAZ & I & I \\
\hline Populus tremula L. & P scap & EAZ & I & III \\
\hline Acer pseudoplatanus L. & P scap & CEMED & I & III \\
\hline Quercus cerris L. & P scap & MED PONT & I & II \\
\hline Pinus nigra Arnold & P scap & CSEM & I & I \\
\hline Vaccinium myrtillus L. & Ch frut & $\mathrm{HOL}$ & I & I \\
\hline Fragaria vesca L. & $\begin{array}{l}\text { H semiros } \\
\text { rept }\end{array}$ & HOL & I & I \\
\hline Dentaria bulbifera L. & G rhiz & EAZ & I & I \\
\hline Prenanthes purpurea L. & H scap & CEUR & I & I \\
\hline $\begin{array}{l}\text { Luzula luzuloides (Lamk.) } \\
\text { Dandy\&Wilmot }\end{array}$ & H caesp & EAZ & I & I \\
\hline
\end{tabular}


Floristic composition and ecologycal analysis of the mixed forests (beech, fir, spruce)... 213

\begin{tabular}{|c|c|c|c|c|}
\hline Anemone apennina L. & G rhiz & MED-SUBMED & I & I \\
\hline Euphorbium amigdaloides L. & H scap & EAZ & I & I \\
\hline Epilobium angustifolium L. & H scap & HOL & I & I \\
\hline $\begin{array}{l}\text { Driopteris filix-mas (L.) } \\
\text { Schott. }\end{array}$ & G rhiz & HOL & $\mathrm{I}$ & I \\
\hline Sorbus austriaca L. & P caesp & CSEM & I & I \\
\hline Hepatica triloba Gilib. & G rhiz & CEUR & I & I \\
\hline Daphne blagajana Freyer & & SEM & I & I \\
\hline Fraxinus excelsior L. & P scap & CEUR & I & \\
\hline $\begin{array}{l}\text { Quercus petraea (Matt.) } \\
\text { Lieblein }\end{array}$ & P scap & CSEM & I & \\
\hline Crategus oxyacantha $\mathrm{L}$. & P caesp & EAZ & I & \\
\hline Sambucus nigra $\mathrm{L}$. & P caesp & EAZ & I & \\
\hline Corylus avellana $\mathrm{L}$. & P caesp & EAZ & I & \\
\hline Rossa canina L. & NP caesp & EAZ & I & \\
\hline $\begin{array}{l}\text { Driopteris dilatata (Hoffm.) } \\
\text { A. Gray }\end{array}$ & G rhiz & HOL & I & \\
\hline $\begin{array}{l}\text { Luzula sylvatica (Huds.) } \\
\text { Gaudin }\end{array}$ & H caesp & SEM & I & \\
\hline Galium odoratum (L.) Scop. & G rhiz & CEUR & I & \\
\hline Anemone nemorosa $\mathrm{L}$. & G rhiz & HOL & I & \\
\hline Juniperus communis L. & P caesp & HOL & I & \\
\hline Veronica urticifolia Jacq. & H scap & CSEM & I & \\
\hline Allium ursinum (L.) Moench. & G bulb & CEUR & I & \\
\hline Epilobium montanum L. & H scap & EAZ & I & \\
\hline $\begin{array}{l}\text { Polystichum aculeatum (L.) } \\
\text { Roth }\end{array}$ & G rhiz & EAZ & I & \\
\hline Mycelis muralis (L.) Dum. & H scap & EAZ & I & \\
\hline Sanicula europaea $\mathrm{L}$. & H scap & EAZ & I & \\
\hline Hypericum maculatum Crantz & H scap & CEUR & I & \\
\hline Festuca drymeia Mert.\& Koch & G rhiz & & I & \\
\hline Senecium nemorensis L. & H scap & & I & \\
\hline Sorbus aucuparia L. & P caesp & CSEM & I & \\
\hline Asarum europaeum L. & Ch rept & EAZ & I & \\
\hline Mercurialis perenis $\mathrm{L}$. & G rhiz & CEMED & I & \\
\hline Nardus stricta L. & H caesp & EAZ & I & \\
\hline Ajuga reptans L. & H rept & CEMED & I & \\
\hline $\begin{array}{l}\text { Neottia nidus-avis (L.) } \\
\text { L.C.Rich. }\end{array}$ & G rhiz & EAZ & I & \\
\hline Pulmonaria officinalis L. & H scap & CEUR & I & \\
\hline Saxifraga rotundifolia $\mathrm{L}$. & H scap & CSEM & & I \\
\hline
\end{tabular}




\section{Spectra of life forms}

The biological spectrum of beech-fir forest has phanerophytehemicryptophyte character, whereby the domination of phanerophyte is insignificant (table 3, graph 1). Significant participation of geophytes indicates to the mesophilic character of this association. Considering that the life form of chamaephyta is well adapted to the unfavourable ecological conditions and that it dominates in the opening habitats, no wonder is its low percentage participation in the spectrum of life forms of Abieti-Fagetum moesiacae association.

Table 3: Spectra of life forms in the associations Abieti-Fagetum moesiacae B. Jov. 1976 and Piceo-Fago-Abietetum Čol.1965.

\begin{tabular}{|c|c|c|c|c|}
\hline Life forms & \multicolumn{2}{|c|}{ Abieti-Fagetum moesiacae } & \multicolumn{2}{c|}{ Piceo-Fago-Abietetum } \\
\hline & $\%$ & $\begin{array}{c}\text { Number of } \\
\text { species }\end{array}$ & $\%$ & Number of species \\
\hline Phanerophyta (P) & 37,28 & 22 & 36,67 & 11 \\
\hline $\begin{array}{c}\text { Hemicryptophyta } \\
(\text { H) }\end{array}$ & 35,59 & 21 & 40,00 & 12 \\
\hline Geophyta (G) & 23,73 & 14 & 20,00 & 6 \\
\hline Chamaephyta (Ch) & 3,39 & 2 & 3,33 & 1 \\
\hline
\end{tabular}

Biological spectrum of beech, fir and spruce community is similar as afore mentioned, the difference is in somewhat greater participation of hemicryptophytes in compare to the phanerophytes (table 3, figure 3). Terophytes did not mention in any of associations, and they are rare elements in these woods, they are typical representations of open and warm habitats.

\section{Spectrum of life forms}

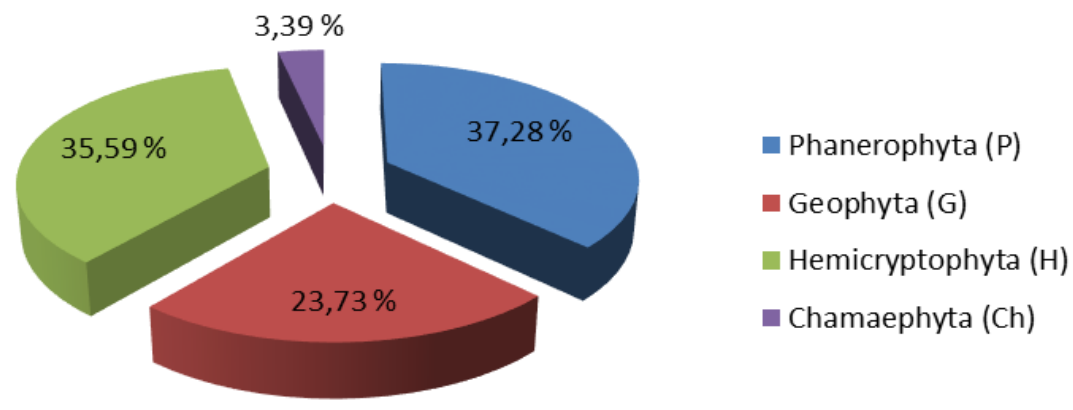

Figure 2. Spectrum of life forms in the association Abieti-Fagetum moesiacae B. Jov. 1976. 


\section{Spectrum of life forms}

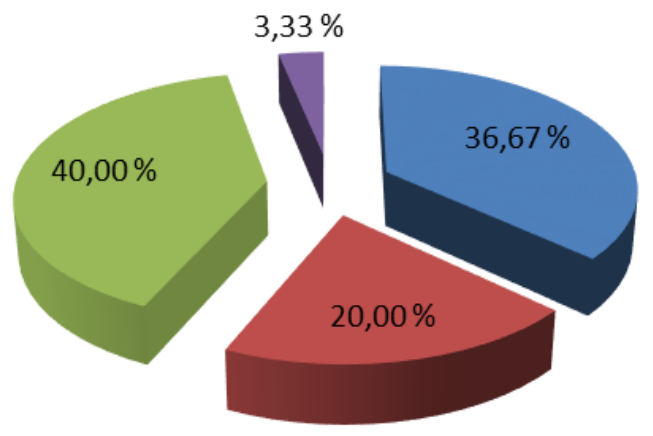

- Phanerophyta (P)

- Geophyta (G)

Hemicryptophyta (H)

- Chamaephyta (Ch)

Figure 3. Spectrum of life forms in the association Piceo-Fago-Abietetum Čol.1965.

\section{Spectrum of areal types}

In the horological spectrum of community Abieti-Fagetum moesiacae B.Jov. 1976 (graph 3) the most represented is Euro-Asian areal type with $33.33 \%$, with mostly eurivalent species with large areale. It is followed by Holarctic areal type with $18.33 \%$, that also containing the species with large areale, and Central-European with $16.66 \%$. The species which areal is mostly Central-European with moderate climate, with smaller part of population that can be spread in the Mediterranean-sub-Mediterranean area, are presented with 8.33\% in chorological spectrum (CEMED). Areal types with species that have the most part of their areal on mountainous belts in Central and/or in Southern Europe are presented with 6.66\% (CSEM) and 3.33\% (CEM). Participation of Mediterranean-sub-Mediterranean areal type is $5 \%$, while cosmopolitan and Mediterranean-Pontic is represented with $1.67 \%$ each.

Regarding to the community Piceo-Fago-Abietetum Čol. 1965. in the spectrum of areal types (Graph 4), the most represented areal types are: Central European (CEUR) and Holarctic (HOL) with 21.87\% each, large percentage has Euro-Asian (EAZ), but with remarkably lesser representing compared to the previous community. In mixed community of fir, spruce and beech following areal types are also represented: Mediterranean-sub-Mediterranean (MEDSUBMED) with three species which consist 9.37\%, Central-EuropeanMediterranean (CEMED) with 6.25\%, Central-European Mountainous (CEM), Cosmopolitan (KOSM) and Mediterranean-Pontic (MED PONT) with 3.12\% each. 


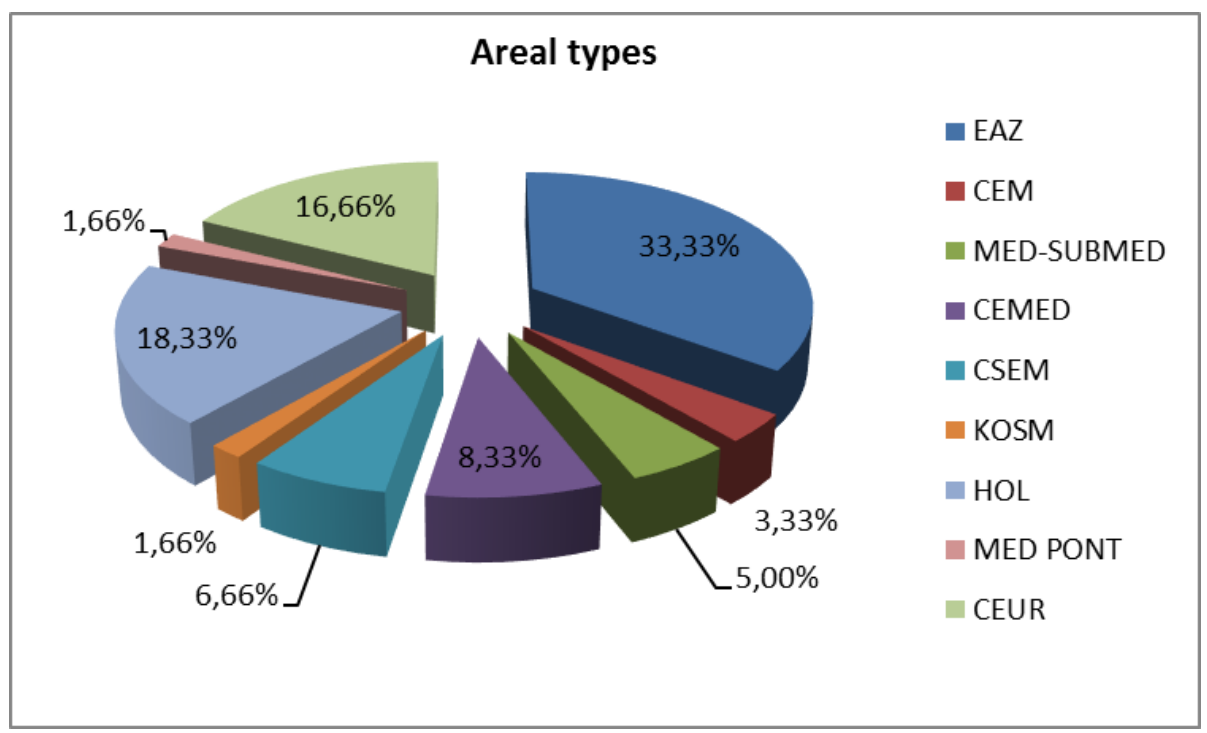

Figure 4. Spectrum of areal types in the association Abieti-Fagetum moesiacae B. Jov. 1976.

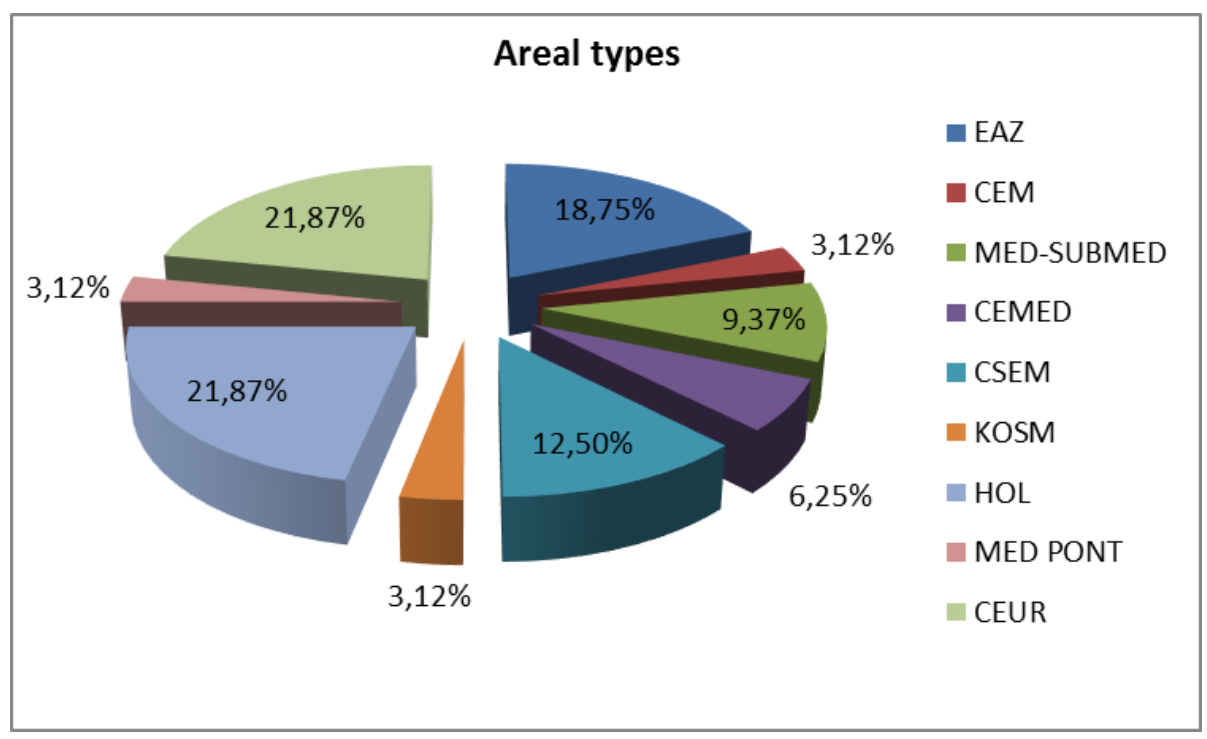

Figure 5. Spectrum of areal types in the association Piceo-Fago-Abietetum Čol.1965.

Horvat (1950) considered that the belt of beech-spruce forests is refugial, because it has smallest changes in compare with other mountainous belts. This belt is situated between warm and dry oak belt, which was markedly changed during the post glaciation (mostly in kserophitisation) and cold and dry subAlpine belt, which rapidly changed during the glaciation and cold periods of post glaciation. Beech-spruce belt continuously had the most favourable conditions 
for survival, and had conserve large number of species and their cenotic groups during the most critical moments in post tertiary history of our flora and vegetation (Janković, 1984).

Association Abieti-Fagetum moesiacae B.Jov. 1976 constitutes climateregional altitude belt in span from 700/800 to 1700/1800 m a.s.l. across the former Yugoslavia (Jovanović, 1959). In Serbia it is developed as powerful climate-regional belt and covers large areas in different orograph, edaphic and microclimatic conditions, extending in different ranges of altitude on different mountainous belts: on Goč Mt 800-1200 m a.s.l. (Jovanović, 1959; Tomića and Cvjetičanin, 1991; Tomić and Jović, 2000), on Kopaonik Mt 1200-1550 m a.s.l. (Mišić and Popović, 1954), on Stara planina Mt 1200-1600 m a.s.l. (Mišić et al., 1978).

In Montenegro beech-fir forests are developed in the central and southern part of the country, where they constitute belt till $600 \mathrm{~m}$ wide (Petrović et al., 2012). They are mentioned on Mediterranean Dinarides, also, where they cover small surface areas, only at northern expositions (Komar, 1995). Regardless to the great economic and ecological importance, systematically investigations of this kind of woods did not provided, and detailed data about its distribution were given only for several mountainous ranges. On a silicate massif of central Bjelasica they extend between 950-1400 m a.s.l. on the northern expositions, while on the southern expositions they form narrower belt between 1200-1550 m a.s.l. On the carbonate massif of north-eastern Bjelasica they cover altitude range 950-1150 m a.s.l. on northern expositions, and 1100 - $1400 \mathrm{~m}$ a.s.l. on the southern expositions (Lakušić et al., 1990). On a vertical profile of mountains around Rožaje this type of forest is mostly extended above the belt of beech forest, while on some localities it constitutes first forest belt (Martinović and Markišić, 2002).

Association Abieti-Fagetum moesiacae B.Jov. in the management unit „Bjelasica“ is extended in wide range of altitudes, from 800 to $1650 \mathrm{~m}$ a.s.l. It covers northern expositions, mostly, that are dominant in the management unit otherwise. Its bedrock is diverse, at higher altitudes it is on the limestone, and on the lower altitudes on the sandstone and shale. The most common lands where this community is developed are brown ground on the limestone, acid and acidbrown grounds.

Mixed deciduous-coniferous community of beech, fir and spruce PiceoFago-Abietetum Čol. 1965. for a long time was considered as a sub-association of beech-fir association, but opinion that it is separate association prevailed (Mišić and Jovanović, 1983). According to the domination of two edificators (beech and fir), floral content and altitude belt this community is closer to the beech-fir type of wood compared to the spruce type. This community is limited at the altitude belt (1000-1550 m a.s.l.) (Jovanović, 1980).

In the management unit „Bjelasica“ association Piceo-Fago-Abietetum Čol. 1965., as well as association Abieti-Fagetum moesiacae B.Jov. 1976, dominantly covers northern expositions. It is spread in the belt from 900 to 1700 
$\mathrm{m}$ a.s.l., resulting in no significant differences within the range of altitudes where associations are present. Due to the northern expositions that are dominates on the investigated area (77\% of surface) and higher humidity as result of several water flows, this association can be spread down at the lower altitudes than usually. The spruce is preserved at lower altitudes (below its belt) thanks to the protection provides from fir and beech. Fir determinates lower and upper limits of this wood by its altitudinal and ecological range. Numbered investigations show that the fir has conspicuous individual and group variability, and in spite of limitation on a particular mountain belt, it inhabits ecologically different habitats with tendency to climb in higher, sub-Alpine regions (Fukarek, 1954, Mišić and Popović 1954, Stefanović, 1970, Jovanović, 1980, Mišić and Jovanović, 1983).

Considering that analyses of biological and horological spectrums of before mentioned forests are not provided in Montenegro, we compare obtained results with spectrums of these forests in Bosnia and Herzegovina (Lisina Mt) and Serbia (Pešter plateau) (Eremija et al., 2015). The great similarity is noticed in the spectrum of life forms between forests of the management unit "Bjelasica" and Lisina Mountain. On both localities hemicryptophytes are dominant and represented with approximately equal percentage (Bjelasica 40\%, Lisina $41 \%$ ), they are followed by phanerophytes that are somewhat numbered on Bjelasica (Bjelasica 36.67\%, Lisina 31\%) and geophytes with equal representation (20\% each). In the biological spectrum of Pešter plateau the order of life forms is the same, but hemicryptophytes significantly dominate (54\%) in compare with phanerophytes (21\%) and geophytes (14\%). So, although the management unit „Bjelasica“ is near to the southern distributional border of communities of beech, fir and spruce, the influence of Mediterranean on biological spectrum is not prominent, because the spectrum is very similar to the same on Lisina, which is located more northern. This indicates that edificators have strong influence on the microclimate conditions in the community, thus on the biological spectrum, also. Similarly conditions are in the horological spectrum in which, on Bjelasica and Lisina Mt, the species group of Central-European floral elements are dominant, and Holarctic floral elements and species of broad ecological amplitude of the Euro-Asian distribution type have high participation.

\section{CONCLUSIONS}

In the management unit „Bjelasica“ analysed associations of mixed deciduous-conifer forests Abieti-Fagetum moesiace B.Jov. 1976 and Piceo-FagoAbietetum Čol. 1965 dominantly cover northern expositions. Their altitude range of extend is similar: first association from 800 to $1650 \mathrm{~m}$ a.s.l., and second from 900 to $1700 \mathrm{~m}$ a.s.l. Beech and fir community is floristically richer (60 species) in compare with the beech, fir and spruce community (30 species).

The biological spectrum of the beech-fir forest has phanerophyticalhemicryptophytical character, whereby the domination of phanerophytes is insignificant, while in the biological spectrum of second community hemicryptophytes are represented in slightly higher percentage in compare with 
phanerophyte. In both communities geophytes have significant participation, hamephytes are represented in small percentage and terophytes are absent.

In the horological spectrum of community Abieti-Fagetum moesiacae B.Jov. 1976 Euro-Asian areal type is most represented with 33.33\%, followed by Holarctic with $18.33 \%$ and Central-European areal type with $16.66 \%$. In the spectrum of areal types of Piceo-Fago-Abietetum association Čol. 1965 the most represented areal types are: Central European and Holarctic with $21.87 \%$ each, Euro-Asian areal type constitutes large percentage (18.75\%), but with noticeably lower representing in compare with previous community. Although the management unit „Bjelasica“ is near to the southern distributional border of communities of beech, fir and spruce, the analysis of biological and horological spectrum did not shown significant influence of Mediterranean.

\section{ACKNOWLEDGEMENTS}

This study was done during project: "Improvement of the forest ecological knowledge base for sustainable forestry and forest conservation in Montenegro" funded by DBU (Deutschen Bundesstiftung Umwelt) and Ministry of Agriculture and Rural Development of Montenegro. The authors would like to thank Prof. Dr. h.c. Albert Reiffor for his valuable advices and help.

\section{REFERENCES}

Braun-Blanquet J. (1964): Pflanzensoziologie, 865 pp. Springer Verlag, Wien.

Cvjetićanin, R. \& Novaković, M. (2010): Floristički diverzitet šume jele, bukve i smrče (Piceo-Fago-Abietetum Čolić 1965) u Nacionalnom parku „Tara“. Glasnik Šumarskog fakulteta, 102: 129-144.

Domac, R. (1994): Mala flora Hrvatske i susjednih područja. Zagreb, Školska knjiga, 503 pp.

Čurović, M. \& Medarević, M. (2011): Glavne karakteristike mješovitih bukovi-jelovih prašumskih zajednica u Nacionalnom parku „Biogradska gora“. Glasnik šumarskog fakulteta, 103: $157-172$.

Čurović, M., Medarević, M., Pantić, D. \& Spalević, V. (2011): Mayor types of mixed forests of spruce, fir and beech in Montenegro. Austrian Journal of Forest Science, 128 (2): 93-111.

Čurović, M., Spalević, V., Medarević, M. (2012): Development of Fir Trees in Mixed Forests of Spruce, Fir and Beech (Piceeto-Abieti-Fagetum) on Mt. Ljubišnja, Kastamonu Univ., Journal of Forestry Faculty (Special issue): 287-292.

Čurović, M., Spalević, V. \& Medarević, M. (2013): The ratio between the real and theoretically normal number of trees in mixed fir, beech and spruce forests in the national park „Biogradska gora“. Agriculture \& Forestry, 59 (1): 7-17, Podgorica.

Ellenberg, H. \& D. Mueller-Dombois (1967): A key to Raunkiaer plant life forms with revised subdivisions. Berichte des Geobotanische Instituts der ETH Stiftung Rübel, 37: 56-73.

Eremija, S., Cvjetićanin, R., Novaković Vuković, M., Rakonjac, Lj., Lučić, A., Stajić, S. \& Miletić, Z. (2015): Study of the floristic composition of fir-spruce-beech forests in Serbia and Bosnia-Hercegovina. Archives of Biological Sciences, 67(4): 1269-1276. 
Fukarek, P. (1954): Istraživanja flore i vegetacije Bosne i Hercegovine. Narodna Štamparija.

Horvat, I. (1938): Biljnosociološka istraživanja šuma u Hrvatskoj. Glasnik šumske pokuse 6: $127-272$.

Horvat, I. (1950): Sumske zajednice Jugoslavije. Nakladni zavod Hrvatske, Zagreb.

Janković, M.M. (1984): Vegetacija SR Srbije; istorija i opšte karakteristike. In: Sarić, M.R. ed.,Vegetacija SR Srbije I, pp.1-166, SANU, Beograd.

Jovanović, B. (1959): Prilog poznavanju šumskih fitocenoza Goča. Glasnik Šumarskog fakulteta, Univerzitet u Geogradu - Šumarski fakultet, 16: 167 - 186.

Jovanović, B. (1967): Dendrologija: sa osnovama fitocenologije. Naučna knjiga, Beograd.

Jovanović, B. (1980): Šumske fitocenoze i staništa Suve planine. Glasnik šumarskog fakulteta, serija A, Šumarstvo posebna izdanja, 55.

Komar, G. (1995): Šume Orjena: 97-112. In: Orjenski masiv, samostalno izdanje, Herceg Novi.

Lakušić, R., Atanacković, B. and Vučković, M. (1991): Prirodni sistem ekosistema planine Bjelasice. In Mijušković, M. \& Lakušić, R. eds. Prirodne i društvene vrijednosti NP „Biogradska gora“, pp. 36 - 52. CANU, Titograd.

MARD (Ministry of Agriculture and Rural Development) Montenegro 2013: The first national forest inventory of Montenegro. Final report. - Podgorica, Montenegro, 2013, 347 pp.

Martinović, Ž. \& Markišić, H. (2002): Priroda Rožaja. Centar za kulturu, Rožaje.

Meusel, L., Jäger, E. \& Weinert, E. (1965): Vergleichende Chorologie der zentraleuropäischen Flora 1. Karten. - Gustav Fischer, Jena.

Meusel, L., Jäger, E. \& Weinert, E. (1965): Vergleichende Chorologie der zentraleuropäischen Flora 1. Text. - Gustav Fischer, Jena.

Meusel, L., Jäger, E. \& Weinert, E. (1978): Vergleichende Chorologie der zentraleuropäischen Flora 2. Karten. - Gustav Fischer, Jena.

Meusel, L., Jäger, E. \& Weinert, E. (1978): Vergleichende Chorologie der zentraleuropäischen Flora 2. Text. - Gustav Fischer, Jena.

Meusel, L. \& Jäger, E. (1992): Vergleichende Chorologie der zentraleuropäischen Flora 3. Text. - Gustav Fischer, Jena, Stuttgart, New York.

Meusel, L., Jäger, E. (1992): Vergleichende Chorologie der zentraleuropäischen Flora 3. Karten, Literatur, Register. - Gustav Fischer, Jena, Stuttgart, New York.

Mišić, V. (1982): Reliktne polidominantne šumske zajednice Srbije. Matica srpska, Novi Sad i Institut za biološka istraživanja „Siniša Stanković“ Beograd, 177 pp.

Mišić, V., \& Popović, M. (1954): Bukove i smrčeve šume Kopaonika. Arhiv bioloških nauka, 6: $12-124$.

Mišić, V., Jovanović-Dunjić, R., Popović, M., Borisavljević, Lj., Antić, M., Dinić, A., Danon, J. \& Blaženčić, Ž. (1978): Biljne zajednice i staništa Stare planine. SANU, Posebna izdanja, Odeljenje prirodno-matematičkih nauka, knjiga 49, 389 pp.

Mišić, V. \& B. Jovanović (1983): Mešovita šuma bukve, jele i smrče (Piceeto-AbietiFagetum moesiacum s.1.) u Srbiji i njen značaj. Zaštita prirode, 36: 33-47.

Ministry of Agriculture and Rural Development (MARD), Montenegro 2013: The first national forest inventory of Montenegro. Final report. - Podgorica, Montenegro, 2013, 347 pp.

Petrović D, Hadžiablahović S, Vuksanović S, Mačić V, Lakušić D (2012): Katalog tipova staništa Crne Gore značajnih za Evropsku uniju. Podgorica-Beograd-Zagreb. 
Pignatii, S. (1982): Flora d' Italia, 1-3.Bolonja: Edagricole.

Stefanović, V. (1970): Die Fichte und Fichtenwälder in Bosnien und Hercegowina in den Vegetationsverhältnissen der Dinariden. Ekologija, 5 (1), Beograd.

Stefanović, V. \& Beus, V. (1991): Šume bukve i jele (Abieti-Fagetum sens.lat.) Dinarida sa aspekta ekološko-vegetacijske rejonizacije Bosne i Hercegovine. In $\mathrm{M}$. Mijušković \& R. Lakušić, eds. Prirodne i društvene vrijednosti NP „Biogradska gora“, pp. 168 - 175. CANU, Titograd.

Stevanović, V. (1992): Floristička podela teritorije Srbije sa pregledom viših horiona i odgovarajućih flornih elemenata. In: Sarić, M. R. (ed.): Flora Srbije 1: 47-56. Srpska akademija nauka i umetnosti, Beograd.

Tomić, Z. \& Cvjetićanin, R. (1991): Zajednica bukve i jele (Abieti-Fagetum serpentinicum Jov. (59)79 emend. Beus 86) na serpentinitima fakultetske šume Goč-Gvozdac. Zbornik radova sa simpozijuma „Nedeljko Košanin i botaničke nauke, Beograd-Ivanjica, (74-82).

Tomić, Z. \& Jović, N. (2000) Tipološka klasifikacija i dinamizam šumskih ekosistema u nastavno-naučnoj bazi na Goču. Glasnik Šumarskog fakulteta, 82: 191 - 214.

Tomić, Z. \& Rakonjac, Lj. (2013): Šumske fitocenoze Srbije. 1-177, Institut of Forestry and Faculty of Applied Ecology, Singidunum university, Belgrade.

Tutin, T.G., Heywood, V., Burges, N.A., Moore, D.M., Valentine, D.H., Walters, S.M. \& Webb, D.A. (1964-1980): Flora Europaea 1-5. - Cambridge: University Press.

Tutin, T.G., Heywood, V., Burges, N.A., Moore, D.M., Valentine, D.H., Walters, S.M. \& Webb, D.A. (1993): Flora Europaea 1. - Cambridge: University Press. 